\title{
掌蹠膿疮症に対する $\mathrm{EQR}$ 療法についての 1 症例とその電気インピーダンスの变化
}

A Case Study of Hand and Finger Dermatitis with EQR Therapy and Changes in Bio-impedances

\section{中部大学工学部 工業物理学科 青 木 孝 志}

1.はじめに

現用医療の大部分は西洋医学を基盤として いる。これは驚異的な進歩をとげ人類に役立 ってきた一方て、様々な問題点をはらんでい る。例えば、最新の医療検査設備により検查 して何も疾患が見つからず、西洋医学的には 問題がなくても、依然として症状を訴えるケ ースはしばしば存在する。また、さまざまな 薬害や弊害をもたらしているし、多くのいわ ゆる難病に対しては良い対策がない。

西洋医学的手法の基本は人体を各器官の部 分部分にわけ、さらにそれを細分化して分析 的に解明しようとする点が特徵である。この ことも勿論重要であるが、東洋医学的手法、 即ち各部分よりも身体全体の調和的機能とか、 生きた身体全体の働きを円滑に保つための統 合的システムの回復治療という思想を付加す る必要があろう。最近は東洋医学のこうした 考えが見直され、臨床にも応用されているこ とは周知のことである。特に慢性病・老人 病・健康維持・予防医学の面から東洋医学の 科学的見直しがなされている。

東洋医学は生体の気血の流れの調整に重き を置く。調整は電気鍼・鋮・炎・温尒・レーザ光 線・遠赤外線・極超短波・等々を用いてなされ ているが、最近は気功も用いられる。最近に なって、中国から広まってきた気や呼吸を基 本とする気功は健康法の一穓として日本社会 にも根をおろしつつある。そして気というも のへの科学的関心も高まってきている。気の 正体が何であるかは末だ科学的に解明される に至っていないとはいえ、気が生体に及畤す
効果については科学的な測定がなされている。 例之ば、気功外気の生体作用について、温 熱效果、生物フォトン効果、皇血球機能への

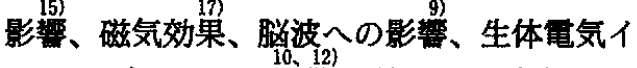
ンピーダンスへの影響、等々の研究報告が なされている。また、治療効果としては、下 肢閉寒性動脈硬化症、潰瘍性大腸炎、慢性肝 炎、癌、難病、等々の治療効果が報告されて いる。

筆者は気功の外気を人工的に発生させる装 置を開発し、これについて既に報告した。こ れは水晶のピエソ垩氮共振システムから発生 する波動 EQR (emission from quartz resonance）を反射電極と反射収束筒を用いて特 定方向に収束させて放射させる構造のもので ある。この波動 $\mathrm{EQR}$ は気功外気の一種であ ることは前に報告した。

前報告において、EQR を照射された健康 成人の皮膚の電気インピーダンスの変化をパ ルス印加法により調查した結果について述べ た。また、EQRの照射前後における自律神 経興奮電流に関係した皮有表面電流(印加電 圧は一定）をノイロメトリーと呼ばれる方法

（直流インピーダンス法）で測定し、電流值 の変化が起こるか否かをプラセボ $\mathrm{EQR}$ 昭射 と比較して統計検定したところ、1\%の有意 水準で有意に起こるという結果を得ている。 これらのことから、EQR は経絡電流の調整 に使用できると考えられる。本報告の目的は $\mathrm{EQR}$ 療法による掌蹠朖疮症の 1 症例と、そ のノイロメトリーによる生体電気インピーダ ンスの変化について報告することにある。 


\section{EQR 装置について}

写真1は EQR 装置の外観である。EQR 装 置については、その基本思想わよび構造の意 味等は前に詳述したので、ここでは簡単に述 べる。

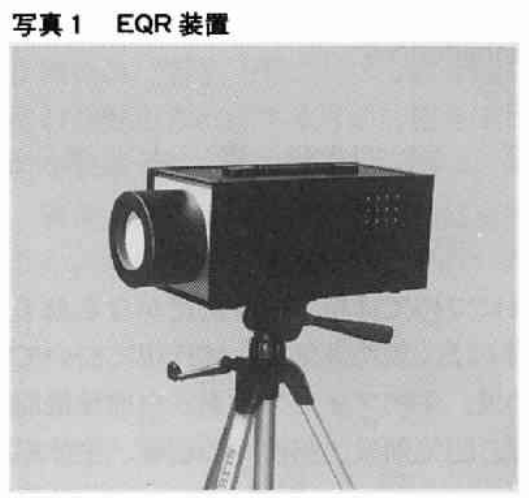

図 1 は $\mathrm{EQR}$ 装置の構造である。図 1 に示 すように、水晶球 (Quartz) は、その中心 のZ 軸を二本の支持具 (Quartz supporter) で挟み支持してある。ここで、Z軸とは水晶 の結晶学上の軸の一つのことである。水晶球 の両脇にハの字型の $\mathrm{Al}$ 製反射電極（Reflecting electrode) をプラスチック板 (Plastic plate) から立ち上げてある。この 電極は二つの働きを有する。一つは水晶球に 共振周波数 $(80 \mathrm{kHz})$ の電界を与えて水晶 球をピエソ共振させ、それにより水晶から波 動 $\mathrm{EQR}$ を発生させること。もう一つは水晶 からの波動 $\mathrm{EQR}$ を反射させて左方に送りだ す働きである。

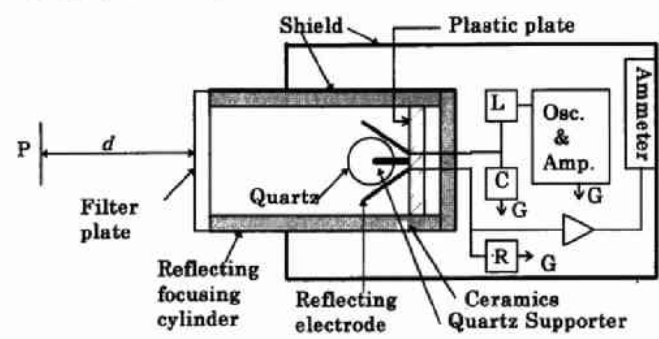

図1EQR 装置の構造。Quartz:球形人工右水晶、 Reflecting electrode:反射電極、Quartz supporter: 水晶支持具、Plastic plate : プラ スチック板、Filter plate : フィルター、d : 照 射距離、 $P$ : 照射位置 (=患者の照射部位)。 除影部分はセラミックスである。
なお、何故、水晶球どそのピエソ共振を用 いたかの理由は、前報告で詳しく説明したが、 ここで簡単にいえば、気功師の発気メカニス ムに関して筆者は"気功師は精神から肉体へ の影響・作用のトレーニングにより、人体内 で熱的または生命的な振動をする結晶的とも 云える生命体特有の螺旋構造の振動を適切な 形態にモデイファイすることができ、それに よって気の波動を作り出す。”とする一つの 仮説を設定し、このことから肉体を非生命の 固体て置き換えるために、螺旋構造をもち、 ピエゾ振動をおこす水晶に着目したのである。

反射収束筒 (Reflecting focusing cylinder）は波動 $\mathrm{EQR}$ を反射させ前方（P の方 向）に収束させる作用をもつ。この波動 EQR を患部に照射して治療を行う装置であ る。 $\mathrm{P}$ は患者の照射位置であり、 $d$ は照射距 離である。

水晶球に必要な大きさの共振電流を流すた めには、印加電界を十分強くする必要がある。 そのため、図 1 に示すように $L C$ 共振回路 を組むことによって、反射電極への供給電圧 を高めてある。ここでCは約 $10 \mathrm{pF}$ である。 ピエソ電気共振の電流を変えると波動 $\mathrm{EQR}$ の強度が変化する。共振電流は低抵抗 Rの電 圧降下を検出して、パネル面の電流計でモニ ターできるようにした。

図 1 に示すフィルター (Filter plate) は、 主に漢方薬を主体としたさまざまな物質によ り構成される板であり、これにより、波動の 最終調整がなされている。

筆者は外気は遠赤外線・赤外線・可視光線・ 紫外線・音波・放射線・磁場・電磁波ではな く、またこれれらを組合わせたものでもないと 考えている。従って、人工外気を作るにあた って、これらの物理量は使わないようにした。 $\mathrm{EQR}$ 装置は前報告で詳述したように遠赤外 線・赤外線・可視光線・紫外線・音波・放射 線等を放出していない。ただ漏洩磁場として、 微弱な磁気成分、即ち照射距離 $d=30 \mathrm{~cm}$ の とき $0.2 \mathrm{mGs}$ より小さな磁気信号を放出す る。この漏洩磁場は生体インピーダンスに変 化を与えたり、治療効果を持つことはない。 
なお因みに、周波数はこれと異なるが、テ レビから出る磁場は、 $3 \mathrm{~cm}$ 距離で25〜 500 $\mathrm{mGs} 、 30 \mathrm{~cm}$ の距離で0.4〜20 $\mathrm{mGs}$ であるこ とが知られている。

$\mathrm{EQR}$ を人に照射すると、敏感な人や疾患 部をもつ人では压感・温感・しびれ感・風の 流動感・蟻走感・まどろみ感などの感覚 $(\mathrm{EQR}$ により起こるひびき）のうちのひとつまたは 幾つかが起き、人によっては体力回復現象・ 沈痛効果などが起きた。生体の不健康部位や 末病部位が敏感に反応しやすい傾向がある。

足達等は、 $\mathrm{EQR}$ を人に照射すると人の体 表面温度の上昇等が起きることを報告してい る。山本等は $\mathrm{EQR}$ をマウスに照射すると、 マクロファージ貧食能の増加が起こることを 報告している。武重等は EQR により家鬼の 脳波の変化および家鬼の松果体細胞の放電の 抑制現象がおこることを報告している。ま た足達等は $\mathrm{EQR}$ を水に照射すると、NMR スペクトルの変化が見られることを報告して いる。上述の現象はいずれも気功師の外気の 作用効果に似ている。

\section{3. 対象および方法}

掌踽膿疱症とは手のひら（掌）と足の裏

（蹠）に無菌性の膿をもった小水泡が沢山で き、進行すると、足の裏と手のひらの皮膚が 厚くなり、角質が剥離し、周辺その他の部位 の皮虚に発赤が起こる病気とされる。大病院 の皮膚科では患者の約 $1 \%$ この病気の患者 であると言われている。

患者（56歳、男、掌蹠膿疮症）は EQR 治 療を始めたのは1996年11月からであるが、そ の約 3 年前の 1993 年 6 月に発症している。初 め左手親指にかさぶたができたので勤務先の 保健室へ行き、そこで渡された塗り薬を使っ たところ 1 2 週間で治疾する。しかしすぐ 再発し $\mathrm{M}$ 病院に通院。そこで、リンデロン VG 塗り薬等を使用するが、左右の両手に湿 疹が拡大する。

そこでS 病院に変えたものの、さらに足に 拡大する。ここで検查とさまざまな薬の治療 を受けるが、一層憎悪する。両手両足がかゆ
くなって水泡ができる。それが破れて膿が出 るという繰り返しとなる。薬を塗り常時包帯 をする。やがて全身の皮虚に波及する。目は 上まぶたが腫れ上がりものもらい状態となる。

そこで、某大学病院に診察に行くとすぐ入 院するようにとのことで入院。そこではステ ロイド阂による治療がなされるが、その時は 一時的に少し良いような感触があっても後一 層憎覀する。全身に赤いブッブッで、それが 盛り上がり、あちこちずるむけ状態で血がに じむ。爪は盛上がりゴツゴツと岩のような外 観を呈し、表面が剝離する。指先はむけて痛 いので包帯をし手袋をはめている。入院した 大学病院の検查では原因不明とされ、治す方 法が不明とされたため、西洋医学に見切りを つけ退院した。

退院後、玄米ご飯、AOA 食品、各種漢方 薬 (塗布薬、飲み薬) など始めたがさしたる 変化なし。全身のかゆみに耐えられない、と いう状態で EQR 治療を開始した。写真 2 は、 EQR 療法を開始した頃の写真であり、(a)は 脚部、(b)は足の裏、(c)は左腕の状態を示して いる。写真 2 (a)、(c)のような発赤が身体のほ ほ全体に渡り見られる。

\section{写真 2 EQR 䖒法を開始 した頃の状態。(a) 脚 部、(b)足の衰、およ び(c)左腕の状龍。身 (a)および(c)のような 発赤が見られる。}

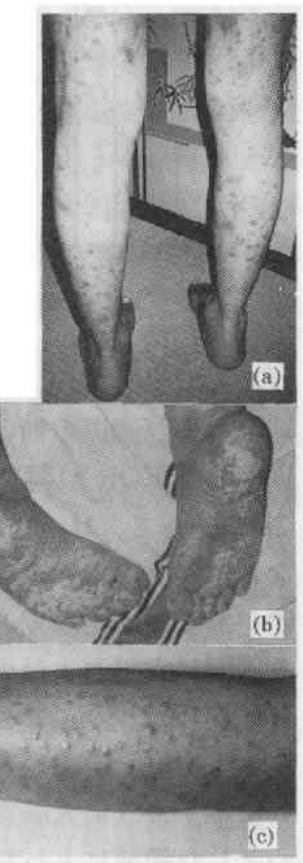


EQR 療法は、ノイロメトリーを行って、 異常を示す経絡とその関連部位に EQR を照 射する方法をとった。ノイロメトリーは全て 電圧 $12 \mathrm{~V} て ゙$ 行った。上述のように水晶を流れ る共振電流が大きいほど波動 $\mathrm{EQR}$ は強くな るが、本実験では共振電流は約 $2 \mathrm{~mA} て ゙$ 使用し た。

また、フィルター板より距離 $d \fallingdotseq 30 \mathrm{~cm}$ 離れ た位置を生体への照射位置とした。照射時間 は合計 1 時間前後で殆ど毎日の照射とした。 $\mathrm{EQR}$ 装置のフィルター(图 1)の材料には、 食塩・酸化カルシウム・ジルコニア・霊芝・
朝鲜人参を混合して用いた。

\section{4、结果および考曻}

初めに、EQR 照射前のノイロメトリーを 行った結果を、中谷によって開発された経絡 診断チャートに黒丸てプロットしたものが図 2 であ。図 2 に示すように照射前は、

$H_{4} 、 H_{5} 、 H_{6} 、 F_{2}$ (右)、 $F_{4}$ (右)、 $F_{5}$ (右)な どが興とでている。この電流パターンから考 えて、便通状況を問診したところ少々便秘状 態であることが分かった。

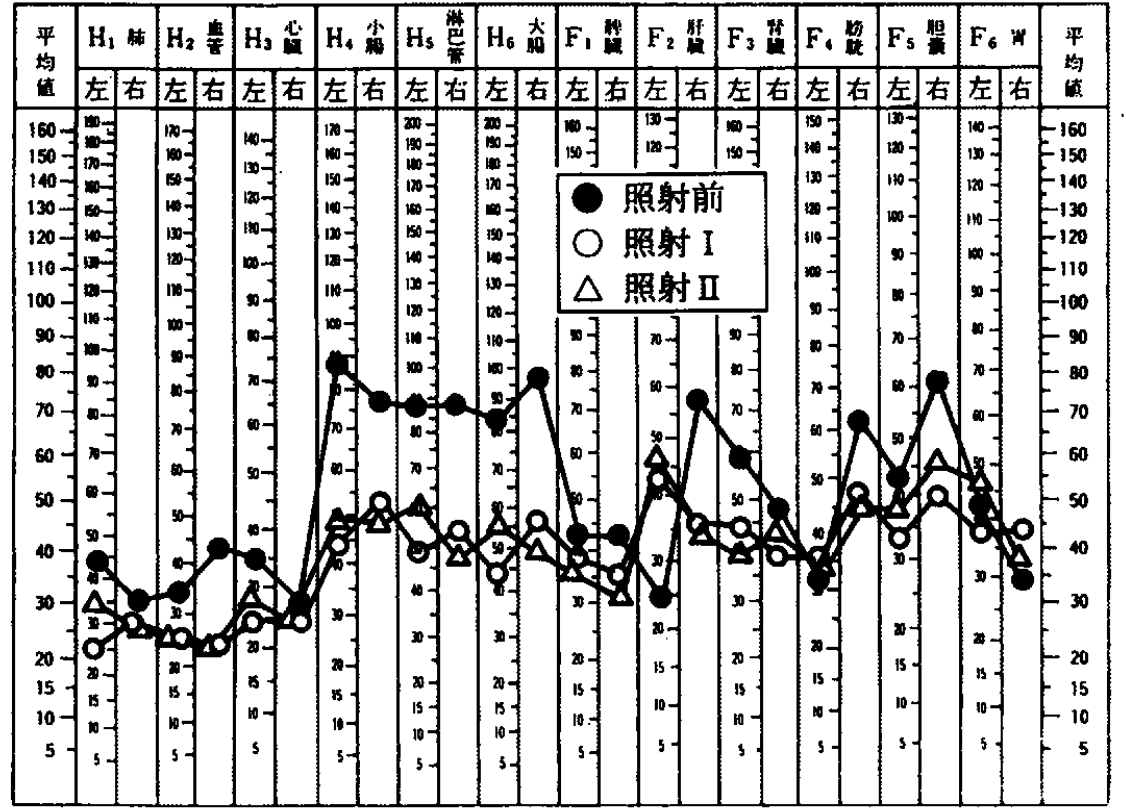

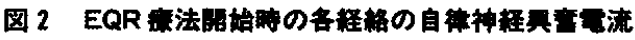

そこで、図 2 のノイロメトリー情報、問診 結果および過去の他の人に対する照射経験を 勘案して EQR 照射を行ったのであるが、図 2 において、 $\mathrm{H}_{5} 、 \mathrm{~F}_{2}$ (右)、 $\mathrm{F}_{4}$ (右)、 $\mathrm{F}_{5}$ (右) などが興とてているのは、これらの経絡に問 題があるのは勿論であるが、この問題の主た る原因は大腸および小腸にあるかもしれない

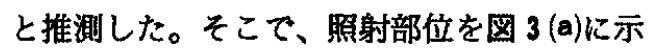
すように関元を中心とした領域、および图 3

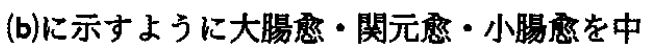
心とした領域にとった。
これらの領域に対して合計て35分照射した 後のノイロメトリーの結果を図 2 に印 (照 射 I）で示した。中谷式経絡喨断チャートに おいては、横軸方向の平坦性がよい場合は経 絡の興锤のバランスが良く健康であるとされ る。図 2 に示すように、EQRの照射により 横軸方向の平坦性が全般的にある程度改善さ れていることが分かる。

EQR のビームには図 3(a)に示すような広

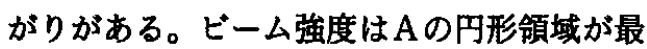
も強い。A領域内の更にその中心領域はもっ 
と強い。A領域の外側のBおよびC 領域へと 拡大するにつれ強度は渐次低下する。C領域 の $\mathrm{EQR}$ 強度はかなり弱く効き目は小さい。 効き目の強い領域はほほA領域である。この ように EQR は鋮负とは異なって、ただ 1 個
の経穴のみを刺激することはできず、かなり 広い領域が一度に刺激されることになる。図 3 (b)では、円形領域Aのみ図示したが図 3 (a) と同じように領域 BおよびCが存在する。 (a)

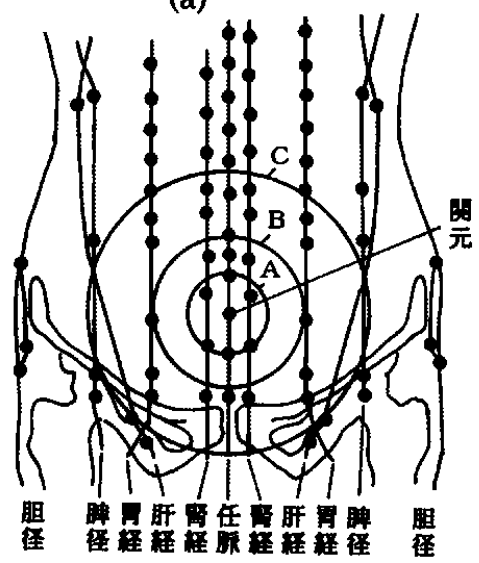

(b)

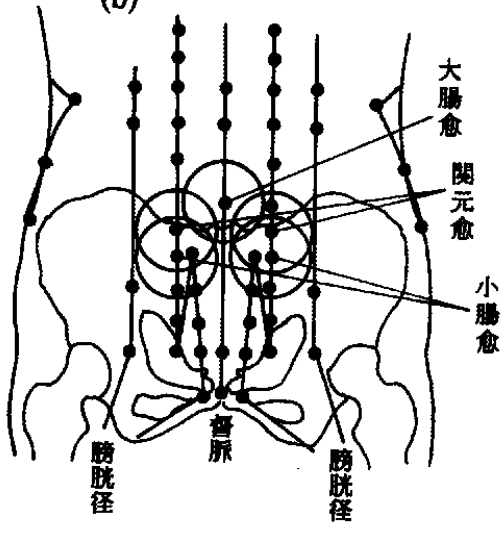

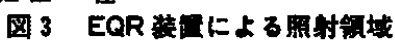

図 2 において、○印（照射 I）のデータを とってから、昼食を挟んで、約 2 時間後に再 び同じ領域に同じ時間（35分）照射し、その 数分後に測定した結果を図 2 の中に $\Delta$ 印（照 射 II) で示した。 $\Delta$ 印 (照射 II) は○印 (照 射 I）と比へててあり大きな変化は見られな い。

照射時には、照射部位がはじめ暖かく感じ た。そして、チクチクまたはピリピリと電気 刺激のような翌きが照射部位の身体内に起こ った。これはやがて涼しい風が体内に吹き込 むような感賞（瑟き）へと変わった。もちろ ん電気をかけたり、ファンで温風や冷風を送 っているわけではなく、単に人工外気 $\mathrm{EQR}$ を照射しているだけである。涼風感は押圧感 を伴うこともあった。照射部位における $\mathrm{EQR}$ 強度の最も強いところ（= A 領域の中 心に、この涼風・押圧の薮きが起こるため、 患者は身体の背面から照射しても、どの位置 に照射がなされているかを言い当てることが でた。

筆者のいままでの経験によると末病部位も 有しないような健常者にはこのような響きは
現れない。ひびきは回復が進むにつれて現れ 難くなり、完全に治筑すると消隇する傾向が あった。また重症なときほど、ひびきは強く 現れる傾向があった。このようなことからし て、本患者は、ひびきの起こる上記照射部位 にさらに照射した方がよいと考えられた。

そこで、一日あたり合計 1 時間前後の照射 を毎日続けたところ、数日のうちに明らかな 効果が現れはじめた。そして日ごとに回復が 進み、盛り上がつた赤いぶつぶつとした全身 のただれが、その盛り上がりが低くなり、色 が黒ずんだ色へと変化しはじめ、かゆみはと れた。約一ヶ月後には消滅するものがかなり 現れた。勿論手袋もとれ、包带は一部の爪先 のみとなった。 3 年間続いていた苦しみが激 減した。

この間、食事は㣂りを無くして、極力バラ ンスをとることと、䄉維質のものを多くとる ようにという指導も、ありふれた指導ではあ るが、行った。織維㙺の摄取は食事面からの 便秘の改善を目的としたものであるが、一方、 EQR 照射によっても胃腸の活性化とそれに よる便秘からの回復を目指した。即ち、これ 
まで他の人に対する照射経験において、胃腸 のみならず会陰からの照射が便意をもよおし たり、放屁を促したりして、腸の活性化をも たらすことをしばしば経験していたのて、本 患者に対しても腸の他に会旡からの照射も行 った。

会旡からの照射は仰向けに夜かせて行った が、肛門がもぞもそとしたり、じんじんと磇 いたりした。EQRの気は会陰から経絡を通 り頭の方に達するため頭の方へもひびきが起 こった。健常者はこのような響きはない。以 上の結果、治療開始後、約 $2 \sim 3$ 週間してほ 浑毎日便通があるようになった。

$\mathrm{EQR}$ 治療を開始から約一ヶ月後のノイロ メトリーの結果を図 4 に示した。図 4 の中で、 黒丸印は照射前の值である。飲酒は極力避け るように告げておいたのだが、照射前まで酒 を飲んでいたため、肝径と胆径の電流值が高 くなっている。そして胃系（右）が低下して
いる。このように経絡電流スペクトルは酒の ため全体的に大暴れの状態である。

图4の中の○印（照射Ｉ）は、照射前の測 定 (黒丸印) を行ってからすぐに、肝愈に15 分照射した後の電流值である。胃系と膀睄径 に変化がみられるだけで、他は殆ど変化して いない。これは飲酒状龍で十分な治蒸時間が とれなかったこともあるが、飲酒はかなり身 体に負担になることを示している。本患者は 回復が進むにつれ飲酒の機会が増え、そのと きは図 4 の黒丸印に例示するように肝径と胆 径が著しく興笛を示すことが多かった。図 4 の中の $\Delta$ 印 (照射 II) は○印（照射 I) より 約 1 週間後に測定したものて、これは、訮 愈・胆覀・脾等に約 1 時間照射してから90 分後のデータである。前データ（○印、図 4) と比べると、肝経も含めて全体的に沈静 化がなされている傾向が現れている。

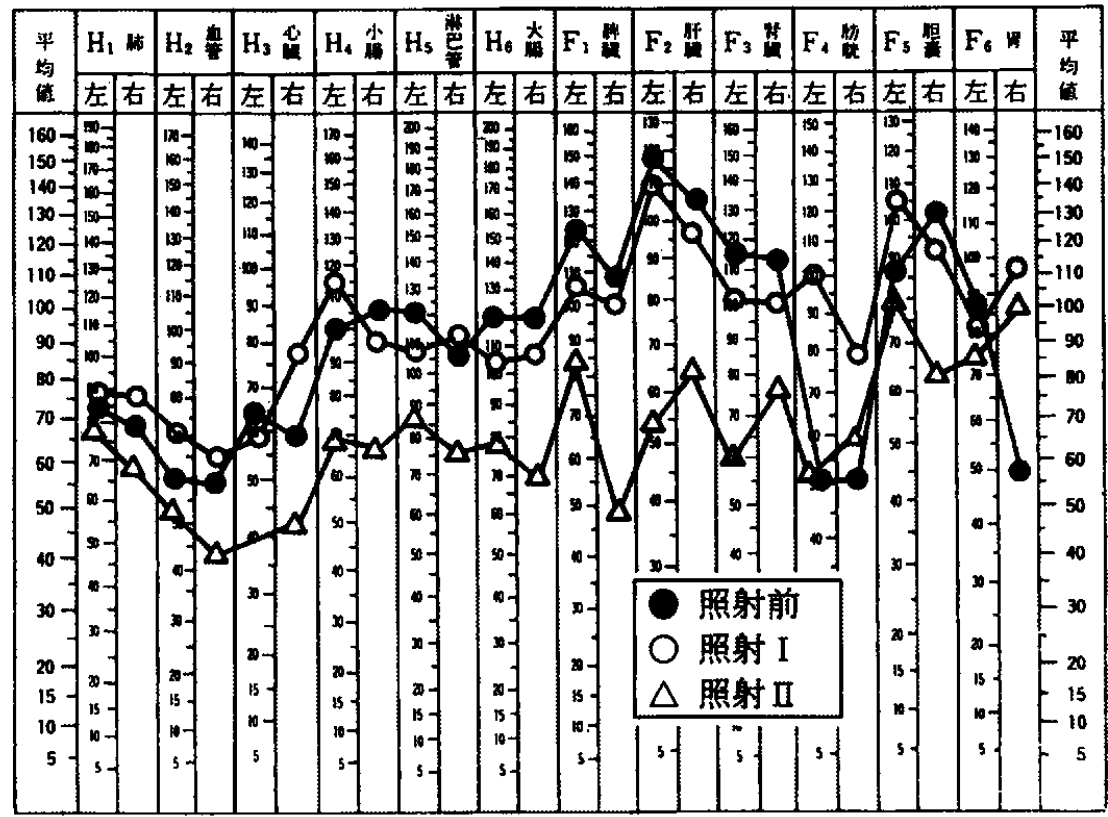

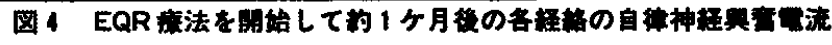

上述のように、 $\mathrm{EQR}$ 装㯰は高すぎる電流 值をもつ経絡の電流値を下げて、自律神経の 興賽しすぎの状態を沈静化する作用をもつ。 しかし、このような㧕制作用しかもたないの ではない。低すぎる電流值をもつ経絡の電流
值は上昇させる効果ももっていることは前報 告で述へたとおりである。

图 5 は EQR 療法を開始してから、約半年 後のノイロメトリーの結果を示している。こ の時点てはもう殆ど皮屑は奇麗になっていた 
が、用心のため毎日照射を続けていた。図 5 は前日に照射してから約24時間後における測 定である。治療開始当初(図 1 の黒丸印)のパ
ターンと比べるとかなり変化していることが 分かる。

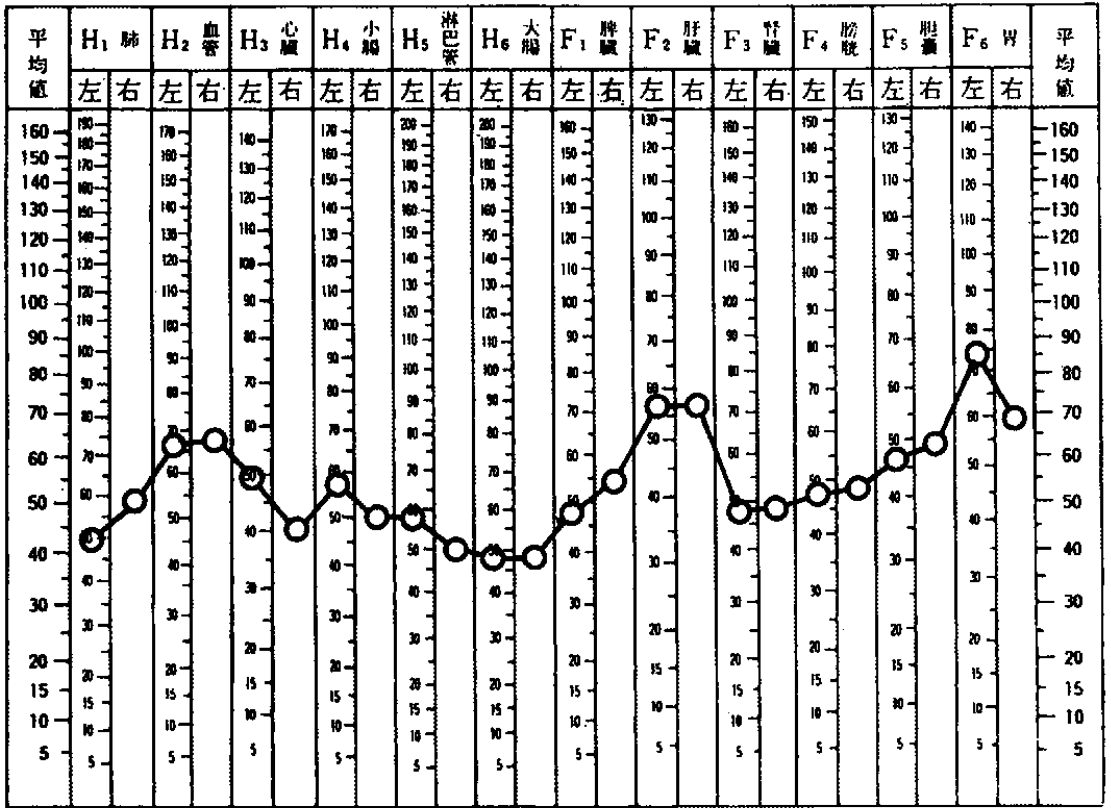

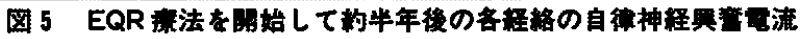

以上、本治療において照射した部位をまと めると、EQR 治療の初期においては上述の ように図 3(a)に示す関元を中心とした領域、 および図 3 (b)に示す大腸意・関元雭・小腸愈 を中心とした領域にとった。約 1 週間後から は、上記のほかに会陰・百会への照射、身体 前面から腹部全体への照射、背面の肝愈・胆 愈・脾愈・胃愈・腎离等への照射、足の裹か らの照射も試みた。しかし総合的にいって大 腸・小腸等の腹部前面とその背面からの照射、 会陰からの照射に照射時間の大半を当てたが、 この照射が顕著な効果をあらわした。

\section{5. おわりに}

$E Q R$ 装置を用いて、掌蹠脹疮症に対する 治療を行なうにあたり、経絡自律神経興審電 流の変化およびひびきの起こり方を手がかり として、食塩・酸化カルシウム・ジルコニア・ 墨蓝・朝鮮人参を混合したフィルターを用い た EQR 照射を行ったところ著効が得られた。 本被験者の場合、飲酒は肝経と胆経の自律
神経の興奮を著しく高め、結果として肝経・ 胆経以外の他の経絡に対しても大きな影響を 与え生体にかなりな負担となり、治療の妨げ となった。

主に、大腸・小腸等の腹部前面とその背面 からの照射、会陰からの照射が本掌瞊膿疮症 患者に対し影著な効果をあらわした。

本症例は、ステロイド刘等を用いた西洋医 学の薬物療法が症状を逆に憎悪させたため、 これらを止め、EQR による気血の流れの調 整一換言すれば良䓕絡自律神経の調整、およ び食物指導という東洋医学的手法を用いて、 それが奏効した一例と考えられる。 


\section{文 献}

1）足達義則、青木孝志、吉福康郎、吉田勝 志： $80 \mathrm{kHz}$ 水晶共振システムが発生する 波動の生体効果のサーモグラフィー解析、 人体科学 6(1)、pp. 93-102、(1997).

2）足達義則、青木孝志、吉福康郎、吉田勝 志： $80 \mathrm{kHz}$ 水晶共振システムが発生する 波動が水に及涩す影䇾の NMR 解析、人 体科学会第 7 回大会抄録集、pp. 25-26、 (Nov. 1997).

3）阿岸鉄三、佐藤雄一、北島久視子、太田和 夫：下肢閉塞性動脈硬化症に対する気功治 療の現代医学的評価、総合臨林、44（9） pp. 2329-2333、(1995).

4) 青木孝志: 気の科学の最近の研究動向、 Jpn. J. Sports Sci. 12(11)pp.681-687、 (1993).

5) 青木孝志： $80 \mathrm{kHz}$ 水晶共振システムが発 生する波動の生体作用の特異例、人体科学、 4-(1)、pp. 11-31、(1995).

6）青木声志： $80 \mathrm{kHz}$ 水晶共振システムから 発生する波動が生体電気インピーダンスに 及理す影警、人体科学、5-(1)、pp. 7582、(1996).

7) 青木孝志: $E Q R$ 装置が生体電気インピー ダンスに及ほす影響、莧理と臨床、7（8）、 pp. 277-281、(1997).

8 ）馮広来戴品忠: 中国・天建大学における気 功による癌治療の臨床報告、人体科学、2 (1) pp. 157-169、(1993).

9) Kawano, K., Koito, K., Fujiki, T. and Shinagawa, Y. :EEG and Topography during Chinese "Qigong" Training, Neurosciences, vol. 16, pp. 503-508, (1990).

10）木戸美：経絡測定による気功の同調現象、 人体科学、2(1)、pp. 19-26、(1993).

11）町好雄：気の測定、人体科学、1（1）、 pp. 19-28、(1992).

12）本山博：AMI と気の流れ、日本良導絡自 律神経学会誌、33(6)、pp. 22-30、 (1978).

13）日本鋮多良过絡医学会編「良導絡自律神経 調整療法一基磁編」、関西錯炎短期大学出 版、(1995).

14）西本真司：気中継装置 HIGH-GENKI II に対する二重亶検試験報告及び溃惕性大腸 炎 1 例、慢性肝炎10気功治療報告、薬理と 臨床、6 (8)、pp. 1572-1576、(1996).

15）丹羽鞄負：医療用電気機器および気功の健 康人・患者白血球機能に及沽す影箘、炎症 12(1) pp. 63-69、(1992).

16）林海：気功運気治療法が難治症に療効、未 踏科学技術、pp. 15、未踏科学技術協会、 東京、1989年11・12月号。

17）瀬戸明：特異な人から放射される生体特殊 磁気輻射の検出について一東洋医学でいう 「気」と生体特殊磁気との関係、日本橧科 東洋医学会誌、9 (2)pp. 36-43、(1991).

18）武重千冬：気功様呼吸による家鬼の脳波変 化、人体科学会第 4 回大会抄録集、pp. 35 -36、 (1994).

19) Takeshige, T. and Aoki, T. : Effect of Artificial and Human External Qigong on Electroencephalograms in Rabbit and Spontaneous Electrical Activity of the Rat Pineal Gland, Acupuncture and Electro-therapeutics Res. Int. J. vol. 19, pp. 89-106、(1994).

20）宇佐史、稲葉文雄：人体からのフォトン放 射、Medical Imaging Technology, 13(1)、pp. 47-54、(1995).

21）山本童隆、盧䫟、青木素志、日下史章、瀬 户明、郭試㻌、佐藤孝雄、笠原多害子、久 光正：磁気扔よび石英単結晶励振波動によ るマウス・マクロファージ貧食能の増加、 磁気と生体 (ISBN-915501-01-8)、 21 (1)、pp. 39-46、(1994).

22）晹浅泰雄：気とは何か、pp. 13-16、NHK Books、(1991). 